\title{
Fine-tuning evolution: germ-line epigenetics and inheritance
}

\author{
Jessica M Stringer, Sanna Barrand and Patrick Western \\ Germ Cell Development and Epigenetics Laboratory, Centre for Reproduction and Development, \\ Monash Institute of Medical Research, 27-31 Wright Street, Clayton, Victoria 3168, Australia
}

Correspondence should be addressed to P Western; Email: patrick.western@monash.edu

J M Stringer and S Barrand contributed equally to this work

\begin{abstract}
In mice, epiblast cells found both the germ-line and somatic lineages in the developing embryo. These epiblast cells carry epigenetic information from both parents that is required for development and cell function in the fetus and during post-natal life. However, germ cells must establish an epigenetic program that supports totipotency and the configuration of parent-specific epigenetic states in the gametes. To achieve this, the epigenetic information inherited by the primordial germ cells at specification is erased and new epigenetic states are established during development of the male and female germ-lines. Errors in this process can lead to transmission of epimutations through the germ-line, which have the potential to affect development and disease in the parent's progeny. This review discusses epigenetic reprogramming in the germ-line and the transmission of epigenetic information to the following generation.

Reproduction (2013) 146 R37-R48
\end{abstract}

\section{Introduction}

Epigenetic mechanisms involve mitotically heritable chromatin modifications that regulate global gene expression patterns and underpin cellular identity and function throughout life. This is achieved through mechanisms involving DNA methylation, histone modifications and non-coding RNAs. Not surprisingly, altered epigenetic states (epimutations) in somatic cells have been associated with a growing list of illnesses including cancer, behavioural disorders and metabolic diseases. In most cases, these altered epigenetic states have only been studied in somatic cells. However, some epigenetic information is transmitted via the gametes to a parent's progeny, in whom it can affect development and fitness.

Gametes originate from the developing germ cells, which establish the essential genetic and epigenetic information required for the zygote to obtain complete developmental potential - a quality known as totipotency. Therefore, germ-line epimutations may have heritable effects on the development of the resulting embryo and may be the cause of a variety of inherited disorders and diseases. Determining how epigenetic information is established in the developing germ-line and the early embryo is crucial for understanding germ-line transmission of the epigenome and how this will affect the next generation.

The genome undergoes two rounds of extensive epigenetic reprogramming during embryonic development. In pre-implantation embryos, specific epigenetic modifications are erased and reset in order to establish essential developmental gene expression patterns (Howlett \& Reik 1991, Santos et al. 2002, Borgel et al. 2010, Smallwood et al. 2011, Gillich et al. 2012, Smallwood \& Kelsey 2012, Smith et al. 2012). However, some epigenetic modifications, such as those that regulate imprinted genes, escape this remodelling and are maintained in somatic lineages into adulthood (Reik et al. 2001, Lane et al. 2003, Weaver et al. 2009, Borgel et al. 2010, Smith et al. 2012; Fig. 1). Genomic imprinting is an inherited epigenetic mechanism that regulates specific genes such that only one of the two inherited alleles is expressed, dependent on its parental origin. Thus, epigenetic modifications regulating these imprinted genes are retained to maintain a parentof-origin genomic identity. A second round of epigenetic reprogramming takes place in the primordial germ cells (PGCs), which found the male and female germ-lines (Seki et al. 2005, 2007, Seisenberger et al. 2012; Fig. 1). This reprogramming is more extensive and includes epigenetic modifications that were maintained during pre-implantation reprogramming (Fig. 1). The erasure of the existing epigenome in PGCs facilitates establishment of sex-specific epigenetic profiles crucial for normal germ-line development and inherited epigenetic mechanisms such as genomic imprinting (Surani 2001, 2007, Surani et al. 2007, Saitou \& Yamaji 2010, Hackett et al. 2013). This review discusses the establishment of the germ-line epigenome, its maintenance in the early embryo and evidence for multi-generational epigenetic inheritance. 


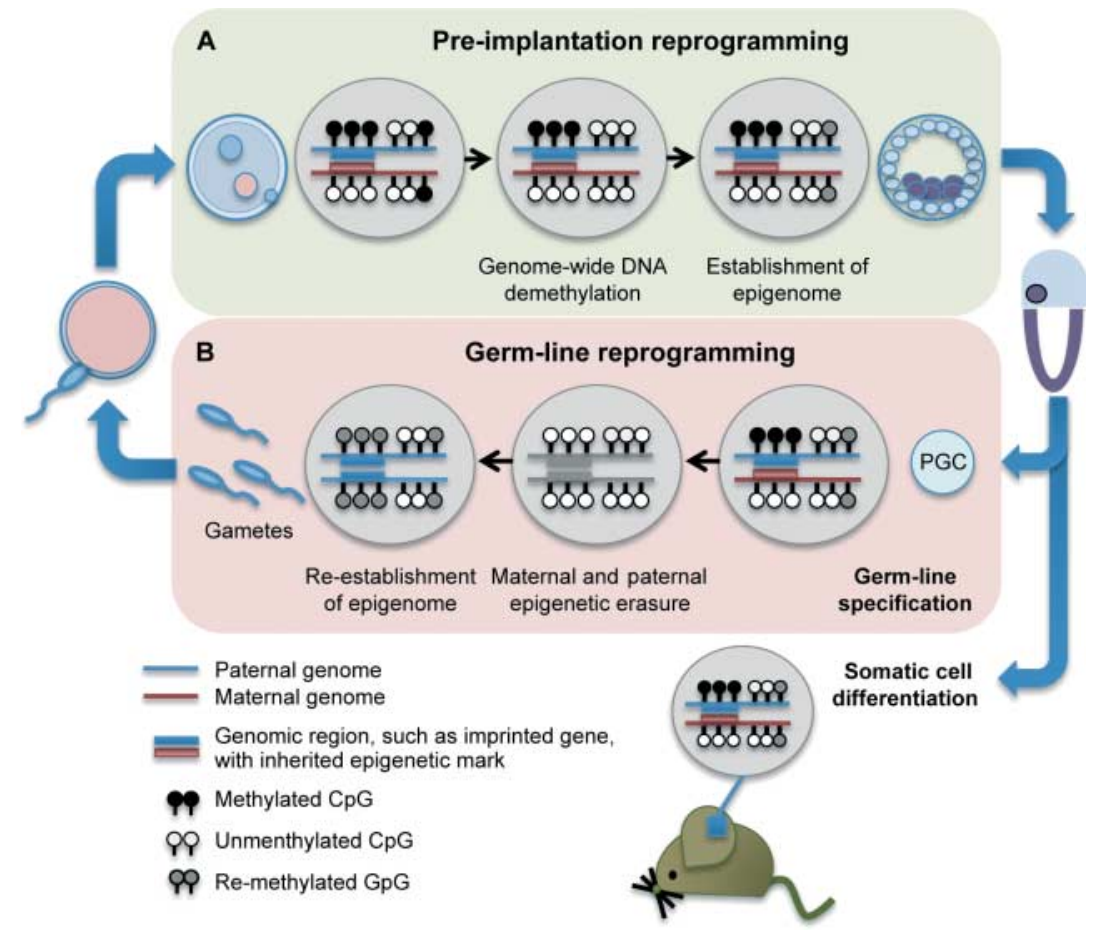

Figure 1 Epigenetic reprogramming during preimplantation and germ-line development in the mouse. (A) In pre-implantation embryos, epigenetic information is erased allowing establishment of developmental specific epigenetic programmes. However, imprinted genes and possibly other inherited epigenetic modifications are protected from this reprogramming and maintained into adulthood. (B) A second, more extensive round of epigenetic reprogramming occurs in the germ-line resulting in epigenetic erasure at non-imprinted genes and imprinted genes. Epigenetic modifications are then re-established in a sex-specific manner.

\section{Germ-line specification and the germ cell epigenome}

In common with other species, including invertebrates such as Caenorhabditis elegans, mammalian germ cell development involves molecular segregation from somatic differentiation and the retention of developmental potential. This is achieved partly through epigenetic mechanisms that repress genes involved in somatic cell differentiation and/or activate genes that promote germ cell identity (Strome \& Lehmann 2007, Saitou \& Yamaji 2010). In mice, proximal epiblast cells give rise to both PGCs and somatic lineages within the embryo. These epiblast cells carry essential epigenetic information, including parent-specific epigenetic marks, which are required for normal somatic development in the embryo (Barton et al. 1984, McGrath \& Solter 1984, Surani et al. 1984, Surani 1991, 1994). Thus, the epigenetic information present in the epiblast must be removed from PGCs following their specification to establish a new sex-specific epigenetic profile appropriate for germ cell function and development (Fig. 1).

In mice, PGC commitment occurs during embryonic (E) days 6-7.25 and is induced by signals from the neighbouring extra-embryonic tissue. These signals induce the production of B-lymphocyte-induced maturation protein 1 (Prdm1 (Blimp1)), which in turn represses a number of somatic genes, such as homeobox genes Hoxa1 and Hoxb1 (Ohinata et al. 2005, Kurimoto et al. 2008a). PRDM1 functions in a complex containing the arginine methyltransferase PRMT5 and establishes methylation of histones, such as histone $2 \mathrm{~A}(\mathrm{H} 2 \mathrm{~A})$ and
H4 (Ancelin et al. 2006). Moreover, PRDM1 and the transcription factor Prdm14 are considered essential for re-expression of genes promoting pluripotency (e.g. Sox2) in early PGCs (Kurimoto et al. 2008b, Yamaji et al. 2008, Magnusdottir et al. 2012). PGC commitment also coincides with repression of the 'de novo' DNA methyltransferases 3a (Dnmt3a) and 3b (Dnmt3b) (Seki et al. 2005, Yabuta et al. 2006, Kurimoto et al. 2008b). Conversely, the maintenance Dnmt1, which adds methyl groups to hemimethylated DNA, is expressed at relatively constant levels in E6.75-E7.75 PGCs and the neighbouring somatic cells (Seki et al. 2005, Yabuta et al. 2006). Based on immunofluorescence, early PGCs also exhibit similar DNA methylation patterns to somatic cells (Seki et al. 2005). Likewise, at E6.5-E7.0, wholemount immunofluorescence revealed similar levels of histone modifications, such as methylation of histone 3 at lysines 4, 9 and 27 (H3K4me2/3, H3K9me1/2/3 and $\mathrm{H} 3 \mathrm{~K} 27 \mathrm{me} 2 / 3$ ) and acetylation of lysine 9 (H3K9Ac), in PGCs and the adjacent somatic cells (Seki et al. 2007). Thus, at specification, PGCs are epigenetically similar to the neighbouring somatic cells but rapidly diverge through the expression of genes, including Prdm1, Prmt5 and Prdm14, that drive PGC specification and repress somatic fate.

\section{Remodelling the early PGC epigenome}

After germ-line commitment, PGCs proliferate and migrate from the base of the allantois, through the hindgut and enter the developing gonad at E10.5 (Fig. 2). 


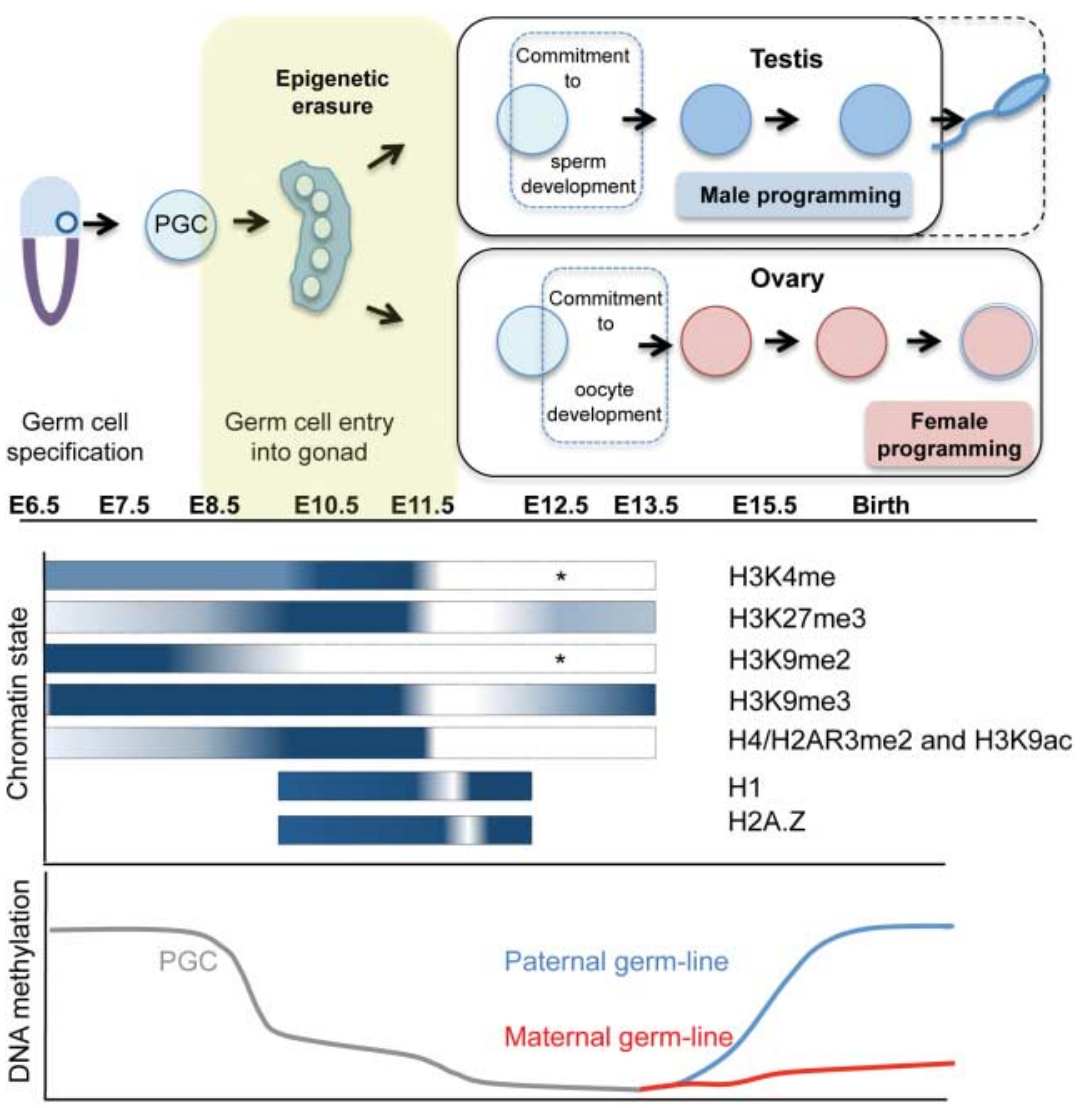

Figure 2 Epigenetic reprogramming relative to developmental events in mouse germ cells. PGCs are derived from the pluripotent epiblast at E6-E7.25 and migrate to the developing gonads by E10.5. During migration, PGCs initiate genomewide epigenetic erasure, including the removal of H3K9me2, significant DNA demethylation and enrichment of H3K27me3. The germ cells enter the gonad at E10.5 and undergo further epigenetic erasure, including the removal of DNA methylation on imprinted genes and TEs. This phase is thought to involve the removal of $\mathrm{H} 3 \mathrm{~K} 27 \mathrm{me} 3$, H3K9me3 and H2A/H4 R3 methylation, removal of histone variants $\mathrm{H} 1$ and $\mathrm{H} 2 \mathrm{~A} . \mathrm{Z}$ and reorganisation of chromatin state. Events primarily based on the reports from Seki et al. (2005), Hajkova et al. (2008) and Kagiwada et al. (2013), although these reports differ in the extent of the chromatin remodelling that takes place. After germ-line sex determination, sex-specific epigenetic modifications are established in the male and female germ-lines. While some re-establishment of $\mathrm{H} 3 \mathrm{~K} 27 \mathrm{me} 3$ and $\mathrm{H} 3 \mathrm{~K} 9 \mathrm{me} 3$ occurs from E12.5, the extent and gene specificity remain unknown. The establishment of other histone modifications (e.g. $\mathrm{H} 3 \mathrm{~K} 9 \mathrm{me} 2$ and $\mathrm{H} 3 \mathrm{~K} 4 \mathrm{me}$ ) also remains poorly described $(*)$. In male germ cells DNA re-methylation is initiated from E15.5 but is not completed until late spermatogenesis. DNA methylation in female germ cells is less extensive and occurs later than in male germ cells.

Between E7.75 and E8.75, PGCs transiently enter G2 cell cycle arrest and undergo genome-wide epigenetic remodelling (Seki et al. 2005). This includes gradual but complete demethylation of $\mathrm{H} 3 \mathrm{~K} 9 \mathrm{me} 2$, which coincides with reduced levels of GLP (EHMT1), a histone methyltransferase that catalyses $\mathrm{H} 3 \mathrm{~K} 9$ methylation (Seki et al. 2005, Tachibana et al. 2005, Yabuta et al. 2006, Seki et al. 2007, Hajkova et al. 2008, Kurimoto et al. 2008b; Fig. 2). Loss of H3K9me2 is followed by enrichment of $\mathrm{H} 3 \mathrm{~K} 27 \mathrm{me} 3$ before the release of PGCs from G2 arrest at E9.0 (Seki et al. 2005, 2007, Hajkova et al. 2008; Fig. 2). Increased levels of methylated arginine 3 in $\mathrm{H} 2 \mathrm{~A}$ and/or $\mathrm{H} 4(\mathrm{H} 2 \mathrm{~A} / \mathrm{H} 4 \mathrm{R} 3)$ have also been reported in PGCs at E8.5 (Ancelin et al. 2006). G2 arrest in PGCs is accompanied by reduced polymerase II-dependent transcription, which may prevent aberrant gene expression during the transition between the repressive modifications, $\mathrm{H} 3 \mathrm{~K} 9 \mathrm{me} 2$ and $\mathrm{H} 3 \mathrm{~K} 27 \mathrm{me} 3$ (Seki et al. 2007). Relatively high levels of the permissive histone marks, H3K9Ac and H3K4me2, were detected in E8.5 and E10.5 PGCs (Hajkova et al. 2008). However, an alternative study detected only a transient up-regulation of H3K9Ac and H3K4me in E10.5 PGCs (Seki et al. 2005). Nevertheless, these data combined indicate that PGC specification initiates a significant period of epigenetic remodelling in these cells.
Upon entry into the gonads, PGCs undergo further chromatin remodelling, including loss of $\mathrm{H} 2 \mathrm{~A} / \mathrm{H} 4 \mathrm{R} 3$ methylation (Ancelin et al. 2006). Similarly, H3K9me3 and $\mathrm{H} 3 \mathrm{~K} 27 \mathrm{me} 3$ are removed from mouse PGCs at E11.5 and re-established soon after (Hajkova et al. 2008), indicating that these histone modifications undergo reprogramming. A similar loss in $\mathrm{H} 3 \mathrm{~K} 27 \mathrm{me} 3$ has also been observed in human PGCs, although levels then remained low (Gkountela et al. 2013). Conversely, alternative reports indicate that $\mathrm{H} 3 \mathrm{~K} 27 \mathrm{me} 3$ is maintained at relatively stable levels in mouse PGCs until E12.5 (Seki et al. 2005, Kagiwada et al. 2013). These data suggest that the reduction of H3K27me3 in PGC at E11.5 may be coupled to fluctuating levels during the cell cycle, rather than epigenetic reprogramming (Kagiwada et al. 2013).

Other aspects of chromatin remodelling have also been observed in conjunction with reprogramming of histone modifications in E11.5 PGCs (Hajkova et al. 2008). These include accumulation of the histone chaperones NAP1 and HIRA in PGC nuclei, rapid depletion of linker histone $\mathrm{H} 1$ and $\mathrm{H} 2 \mathrm{~A} . \mathrm{Z}$ and morphological changes such as expansion of nuclei and temporary loss of visible chromophores (Hajkova et al. 2008). Based on the rapid nature of this process, the authors suggested that histone modifications 
are reprogrammed through a histone replacement mechanism (Hajkova et al. 2008). In accord with this, histones, including $\mathrm{H} 1$ and $\mathrm{H} 2 \mathrm{~A} . \mathrm{Z}$, were detected in the cytoplasm of a few PGCs, indicating that they might be transported for degradation (Hajkova et al. 2008). However, PGCs lacking a H3K27me2/3 demethylase, UTX (Kdm6a), have aberrant chromatin dynamics and fail to form pluripotent embryonic germ cells (Mansour et al. 2012), indicating that UTX, and similar enzymes, may also be involved in the removal of histone modifications from PGCs. Another recent study did not detect the chromatin changes reported by Hajkova et al. (2008) and suggests that a histone replacement mechanism is unlikely to regulate reprogramming at this time (Kagiwada et al. 2013). The reason for the differences between these studies remains unclear, but it is apparent that the extent of chromatin reprogramming and mechanisms involved in resetting histone modifications remain to be clarified. Nevertheless, such mechanisms could play an important role in providing an epigenetic ground state for the establishment of sexspecific histone modifications in PGCs that influence the development in the next generation.

In addition to histone remodelling, PGCs undergo extensive genome-wide DNA demethylation, which is initiated in migrating PGCs and completed by E13.5, after population of the gonads (Popp et al. 2010, Guibert et al. 2012, Seisenberger et al. 2012, Hackett et al. 2013, Kagiwada et al. 2013). Recent genome-wide profiling of DNA methylation using bisulphite sequencing demonstrated that global DNA methylation is decreased from 71 to $30 \%$ in PGCs between E6.5 and E9.5 and further decreased to 14 and $7 \%$ after entry of PGCs into the developing testis and ovary respectively (Seisenberger et al. 2012). Importantly, this wave of DNA demethylation includes genomic regions that initially preserved their methylated state during the zygotic reprogramming (e.g. imprinted genes). Moreover, the majority of imprinted gene differentially methylated regions (DMRs) methylation is maintained during migration, and demethylation of these regions is only completed once PGCs enter the genital ridges from E10.5 (Seisenberger et al. 2012). This is consistent with the notion that PGCs need to enter the gonad before erasure of imprints is initiated, perhaps by signalling from the somatic cells (Surani 2007). However, analyses based on the dynamics of 5-methylcytosine $(5 \mathrm{mC})$ and 5 -hydroxymethylcytosine $(5 \mathrm{hmC})$ suggest that erasure of some imprints commences before the entry into the genital ridges, although gene-by-gene differences in demethylation rates were noted (Hackett et al. 2013, Kagiwada et al. 2013). This indicates that the process is temporally defined and its initiation may be independent of gonadal signals. DNA demethylation during this period also includes transposable elements (TEs) such as LINE and SINE's, although intracisternal-A-particles (IAPs) remain methylated. Interestingly, demethylation of
LINE1 elements in germ cells did not result in aberrant expression (Seisenberger et al. 2012). This suggests that other mechanisms are in place to repress transcription during this phase of reprogramming (Seisenberger et al. 2012). These could include RNA binding proteins, which are highly represented in PGCs and a number of other mechanisms. In PGCs, there are a subset of genes that suppresses TE activity, including Tex19.1, Mili, Mov10l1 and Asz1. A recent report demonstrates that these genes are primarily regulated by DNA methylation, rather than histone modification (Hackett et al. 2012). Moreover, as transcriptional activity was detected for these genes during reprogramming, it was suggested that they may provide a mechanism to silence TEs in the absence of methylation, thereby protecting genome integrity (Hackett et al. 2012).

While the genome is hypomethylated in both sexes by E13.5, methylation is retained at some loci (Seisenberger et al. 2012, Hackett et al. 2013). Most recently inserted retrotransposon sequences, particularly IAPs, are substantially resistant to demethylation in PGCs, ensuring their repression and maintaining genome integrity (Lane et al. 2003, Popp et al. 2010, Guibert et al. 2012, Seisenberger et al. 2012, Hackett et al. 2013). However, some single-copy $\mathrm{CpG}$ islands (CGIs) in the genome were also found to be resistant to demethylation (Seisenberger et al. 2012, Hackett et al. 2013). Although the functional significance of this remains unknown, these CGls may provide candidates for inter-generational epigenetic inheritance (Seisenberger et al. 2012, Hackett et al. 2013), which is discussed in more detail later in this review.

The mechanisms involved in removal of methyl groups from DNA in mammalian PGCs remain a matter of debate. Recent studies have provided substantial insights into this process but disagree on whether passive and/or active mechanisms are involved. Of the known enzymes required for DNMT activity (including Dnmt1, Dnmt3a/b/l and Uhrf1), all but Dnmt1 are downregulated in PGCs after E7.25-E7.5 (Hajkova et al. 2002, Seki et al. 2005, Yabuta et al. 2006, Kurimoto et al. 2008a, Kagiwada et al. 2013). As UHRF1 is required for recruitment of DNMT1 and maintenance methylation (Sharif et al. 2007), it is highly unlikely that PGCs undergoing demethylation contain DNMT activity. Therefore, when PGCs are highly proliferative, it is likely that passive, replication-dependent reduction contributes significantly to DNA demethylation. However, active mechanisms are also thought to contribute to PGC demethylation. Activation-induced cytidine deaminase (AID)-dependent DNA demethylation has been proposed to mediate DNA demethylation in PGCs that have entered the developing gonads. However, only a moderately higher level of DNA methylation is maintained in germ cells deficient for AID, suggesting other mechanisms are involved (Bhutani et al. 2010, Popp et al. 2010). The base excision repair (BER) and the ten to 
eleven translocation (TET) pathways have also been implicated in DNA demethylation in PGCs and during reprogramming in the zygote, ES cells and preimplantation embryos (Hajkova et al. 2010, Ito et al. 2010, Hackett et al. 2012). However, of the genes involved in the three known active demethylation pathways (TET, AID and BER pathways), substantial levels of transcription were observed only for Tet1, suggesting that only the TET1-TDG pathway can operate in PGCs (Kagiwada et al. 2013). Moreover, Tet1-deficient PGCs have been shown to undergo genome-wide DNA demethylation (Yamaguchi et al. 2012), suggesting that Tet1 is not required for demethylation in PGCs. In contrast, another study detected both TET1 and TET2 protein in PGCs undergoing reprogramming between E9.5 and E11.5 (Hackett et al. 2013). This expression coincided with a reduction of $5 \mathrm{mC}$ and an elevation of 5hmC (Hackett et al. 2013). Additionally, microRNA knockdown of Tet1 and Tet2 in PGCs blocked DNA demethylation, while constitutive overexpression promoted $5 \mathrm{mC}$ erasure (Hackett et al. 2013). This provides substantial evidence of the involvement of TET-mediated $5 \mathrm{mC}$-to-5hmC conversion in demethylation. After conversion, levels of $5 \mathrm{hmC}$ declined between E10.5 and E13.5, which correlated with the rate of DNA replication suggesting that clearance of $5 \mathrm{hmC}$ is a passive process (Hackett et al. 2013). Furthermore, analysis using hairpin bisulphite sequencing allowed the identification of hemimethylated sequences in PGCs at E9.5 and E10.5, which were subsequently completely unmethylated by E13.5 (Seisenberger et al. 2012). Thus, it appears that DNA demethylation in PGCs is likely to employ both active and passive mechanisms.

Epigenetic reprogramming of PGCs is rapidly followed by germ-line sex determination, which sets the bipotential PGCs on a path to produce either male or female gametes. Sex-specific germ-line development is marked by the entry of $X Y$ (male) germ cells into mitotic arrest and XX (female) germ cells into meiosis, processes that involve signalling by Fgf9, Nodal, Tgf/Activin and retinoic acid (Baltus et al. 2006, Koubova et al. 2006, DeFalco \& Capel 2009, Western 2009, Bowles et al. 2010, Miles \& Western 2012, Souquet et al. 2012, Spiller et al. 2012, Miles et al. 2013). Although poorly understood, these signalling mechanisms are associated with important changes in gene expression profiles, including the repression of genes that regulate pluripotency (e.g. Pou5f1 (Oct4), Sox2 and Nanog) and activation of genes that drive sex-specific germ-line development. These programs also drive establishment of sex-specific epigenetic profiles important for gametogenesis and development in the next generation.

\section{Re-establishment of the germ-line epigenome}

Epigenetic erasure in the germ-line creates a chromatin landscape permissive for re-establishment of the male and female epigenomes. Although there is global re-methylation of $\mathrm{H} 3 \mathrm{~K} 27 \mathrm{me} 2 / 3$ and $\mathrm{H} 3 \mathrm{~K} 9 \mathrm{me} 3$ in both XX and XY germ cells from E12.5 (Hajkova et al. 2008; Fig. 2), the extent and higher resolution patterning of these and most other epigenetic modifications remain unknown. However, the re-establishment of DNA methylation has been more extensively studied, particularly at imprinted loci and TEs. Re-establishment of DNA methylation is mediated by the de novo DNMTs (DNMT3A and DNMT3L), which are strongly up-regulated in quiescent male germ cells. Conditional knockout studies have demonstrated that both Dnmt3a and Dnmt $3 /$ are essential for re-methylation of imprinted genes and for methylation of other sequences including TEs (Bourc'his et al. 2001, Chedin et al. 2002, Hata et al. 2002, Bourc'his \& Bestor 2004, Kaneda et al. 2004, Sakai et al. 2004, Webster et al. 2005, Kato et al. 2007, Lucifero et al. 2007, Shovlin et al. 2007).

Genomic imprinting is an inherited epigenetic state that results in a parent-of-origin-specific expression of $\sim 140$ genes, transposons and microRNAs in the therian (eutherian and marsupial) mammals (http://igc.otago.ac. nz/home.html and http://www.mousebook.org/catalog. php?catalog=imprinting). The molecular mechanisms regulating genomic imprinting are well characterised at only a few loci (Constancia et al. 1998, Reik \& Walter 1998, Edwards \& Ferguson-Smith 2007, Ideraabdullah et al. 2008, Sha 2008, Kim et al. 2009). However, the majority of imprinted genes are marked by DNA methylation (or histone modifications) that differs between the maternal and paternal alleles and is thought to regulate parent-specific expression of the gene(s) at that locus (Fig. 3). Establishment of parent-specific DNA methylation (differential methylation) at imprinted loci occurs within the male and female germ-lines and is maintained through zygotic reprogramming, possibly by mechanisms involving DNMT1, DPPA3/Stella and TRIM28 (Nakamura et al. 2007, Cirio et al. 2008, Messerschmidt et al. 2012), and in many somatic tissues throughout life (Reik \& Walter 2001, Bartolomei \& Ferguson-Smith 2011). In mice, male germ cells acquire DNA methylation from around E15.5, coinciding with a male germ cell-specific period of mitotic arrest. Imprinted genes such as Rasgrf1, Meg3 (Gt/2) and H19 start to acquire methylation in male germ cells between E12.5 and E17.5 but are not completely methylated until late spermatogenesis (Li et al. 2004). In contrast, female germ cells acquire methylation after birth, although the levels of DNA methylation may be significantly lower than those in the sperm (Davis et al. 2000, Li et al. 2004, Lucifero et al. 2004, Smith et al. 2012).

Imprinted genes are usually located in clusters and are co-regulated by imprinting control regions (ICRs) that contain DMRs. In developing germ cells, DNA methylation inherited from the previous generation is erased and is re-established in a sex-specific manner at DMRs, single-copy genes and TEs. For example, paternally 


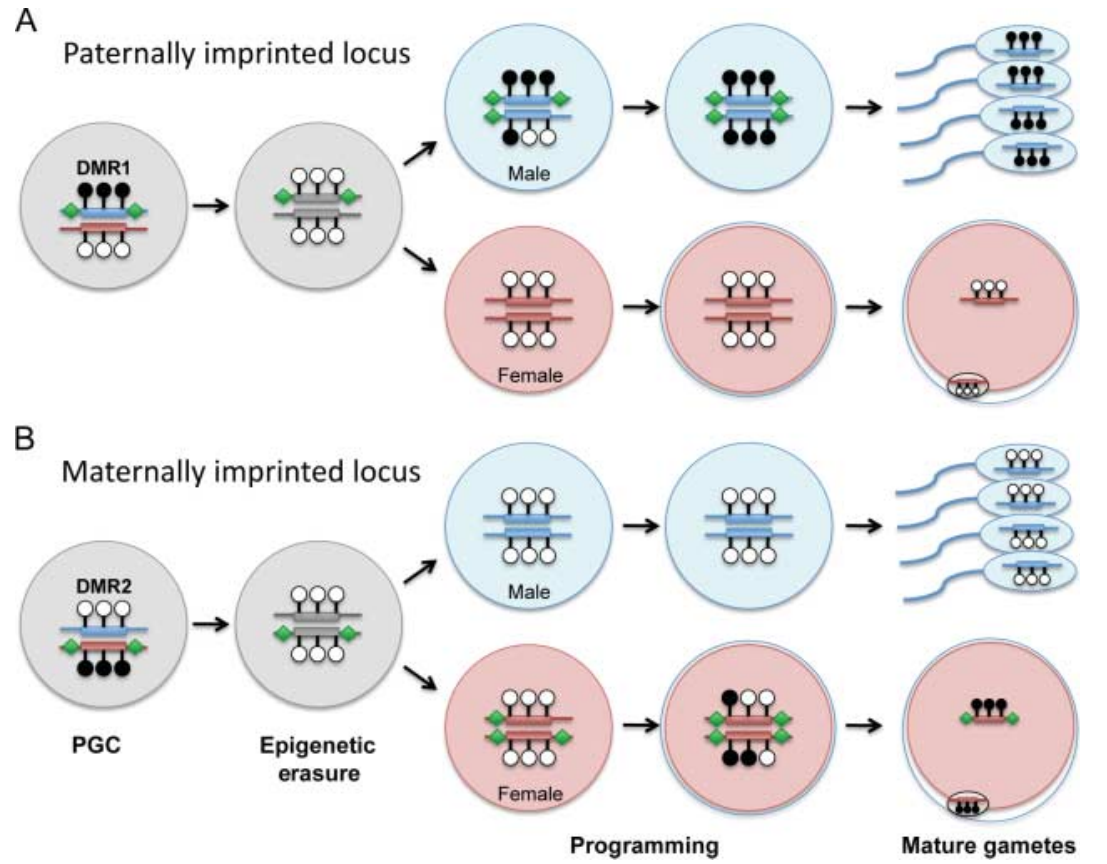

Figure 3 Epigenetic erasure and establishment of a paternally and maternally imprinted locus in male and female germ cells. In the PGCs, the blue allele was inherited from the father and the pink allele was inherited from the mother. New parent-specific epigenetic marks are acquired after germ cell sex determination. Black circles represent methylated $\mathrm{CpG}$ sites and open (white) circles indicate unmethylated sites. (A) A paternally imprinted gene acquires methylation on both alleles in the male germ-line while the female germ-line remains unmethylated. (B) A maternally imprinted gene acquires methylation on both alleles in the female germ-line while the male germ-line remains unmethylated. Other epigenetic marks (green diamonds) may be maintained during germ-line epigenetic erasure and direct the establishment of the new parent-specific marks such as DNA methylation. DMR, differentially methylated region. methylated DMRs become methylated on both alleles in male germ cells but remain unmethylated in female germ cells (Fig. 3). Interestingly, remethylation of germline DMRs may occur asynchronously. For example, at the mouse H19 ICR, the previously methylated paternal allele becomes re-methylated before the previously unmethylated maternal allele (Davis et al. 1999, 2000, Li et al. 2004). As both alleles exist in an unmethylated state after erasure, other marks must be retained to direct re-methylation to the appropriate sites in an ordered manner (Fig. 3). In somatic cells, the methylated allele within ICRs is associated with H4K20me3 and $\mathrm{H} 3 \mathrm{~K} 9 \mathrm{me} 3$, while the unmethylated allele is enriched for $\mathrm{H} 3 \mathrm{~K} 4 \mathrm{me} 2$ and acetylated $\mathrm{H} 3$ (H3ac; Delaval et al. 2007, Henckel et al. 2009, Arnaud 2010). Similarly, $\mathrm{H} 3 \mathrm{~K} 4 \mathrm{me} 2$ and $\mathrm{H} 3 \mathrm{ac}$ are enriched at unmethylated ICRs before the global exchange of histones for protamines in spermatogonia (Delaval et al. 2007, Henckel et al. 2009, Arnaud 2010). Maternal DPPA3/Stella, TRIM28 and $\mathrm{H} 3 \mathrm{~K} 9 \mathrm{me} 2$ may be required for maintaining imprints in the zygote (Nakamura et al. 2007, Messerschmidt et al. 2012, Szabo \& Pfeifer 2012). Interestingly, G9a, a euchromatin-localised histone methyltransferase, catalyses $\mathrm{H} 3 \mathrm{~K} 9$ dimethylation and is required for the establishment of methylation at specific loci (Dong et al. 2008, Tachibana et al. 2008, Ikegami et al. 2011, Leung et al. 2011). Combined, these studies led to speculation that histone modifications marking allele-specific methylation may contribute to the maintenance of imprinting during zygotic reprogramming (Delaval et al. 2007, Abramowitz \& Bartolomei 2012).

Repetitive DNA elements, including minor satellite sequences and some TEs, such as IAPs maintain a relatively high level of methylation during epigenetic erasure and are completely remethylated by E17.5 (Hajkova et al. 2002, Lane et al. 2003, Lees-Murdock et al. 2003, Seisenberger et al. 2012). DNA methylation of these elements prevents their transposition during germ-line development, thereby maintaining genome integrity. Methylation of TEs involves small RNAs, particularly P-element-induced wimpy testes (PIWI)interacting small RNAs (piRNAs). piRNAs interact with PIWI-like proteins and functionally related TUDOR proteins, with piRNAs guiding RNA-induced transcriptional silencing, de novo DNA methylation and potentially the establishment of histone methylation (e.g. H3K9me3 and H3K9me2) on target sequences (Aravin \& Bourc'his 2008, Aravin et al. 2008, Kuramochi-Miyagawa et al. 2008, Siomi et al. 2011, Bamezai et al. 2012). The extent to which the PIWI-piRNA axis is required for other, non-constitutive epigenetic regulation in the developing germ-line remains unclear. However, PIWIs may interact with piRNAs to direct DNA methylation and histone modifications that mediate both silencing and activation of target genes (Bamezai et al. 2012).

Ultimately, these and other mechanisms result in establishment of the epigenetic modifications within the gametes that are transmitted to the next generation. As most nucleosomes are replaced by protamines during spermatogenesis (Balhorn et al. 1977, Gatewood et al. 1987), it has long been thought that histones play an insignificant role in transmission of this information through the male germ-line. However, some nucleosomes are retained and are preferentially located at the promoters of developmental regulators, such as 
Hox genes, Sox2, Brachyury(T), Cdx2 and Gata6 (Tanphaichitr et al. 1978, Gatewood et al. 1987, Hammoud et al. 2009, Brykczynska et al. 2010). Therefore, the maintenance of histone modifications in sperm may provide a mechanism to control expression of specific gene sets in the next generation and for the embryo to recognise the paternally inherited genome (Tanphaichitr et al. 1978, Gatewood et al. 1987, Hammoud et al. 2009). It remains unclear when this information is established during sperm development and whether these histone modifications regulate paternal gene expression in the father's progeny. However, recent studies on $C$. elegans have functionally linked piRNAs and histone modifications to multi-generational epigenetic inheritance (Ashe et al. 2012, Buckley et al. 2012, Gu et al. 2012). These studies provide a link between epigenetic patterning in the developing germ-line and a memory mechanism that facilitates transmission of this information to the next generation.

\section{Multi-generational epigenetic inheritance}

It has been widely speculated that the germ-line epigenome is subject to alteration by environmental influences, thereby allowing evolutionary adaptation through mechanisms such as epigenetic modifications. An increasing number of studies suggest that exposure of a pregnant mother to particular environmental influences could alter the epigenome in the fetal somatic and/or germ cells (Fig. 4a; Anway et al. 2005, Skinner \& Guerrero-Bosagna 2009, Skinner 2010). For example, potential epigenetic effects were reported in individuals who experienced the Dutch Hunger Winter (1944-1945). Nineteen-year-old men who were pre-natally exposed to this famine had different phenotypes depending on the timing of exposure. Malnutrition during the first trimester of pregnancy resulted in higher rates of obesity than exposure in the last trimester (Ravelli et al. 1976). Similarly, the imprinted IGF2 gene was less methylated in individuals exposed to famine in the peri-conception period compared with their unexposed, same-sex siblings (Heijmans et al. 2008). Although these observations are of significant interest, it is very difficult to determine whether these environmental factors cause changes in the F1 germ-line and are transmitted to the following generations in human subjects (Fig. 4a).

To circumvent these limitations, other models have been investigated. Analyses of rodent models have revealed altered glucose metabolism (e.g. reduced insulin secretion and insulin resistance) in pups born to malnourished mothers. Interestingly, similar phenotypes were observed in the second and third generations (Dahri et al. 1991, Martin et al. 2000, Benyshek et al. 2004, 2006). However, the second-generation animals were bred from F1 dams with reduced insulin secretion
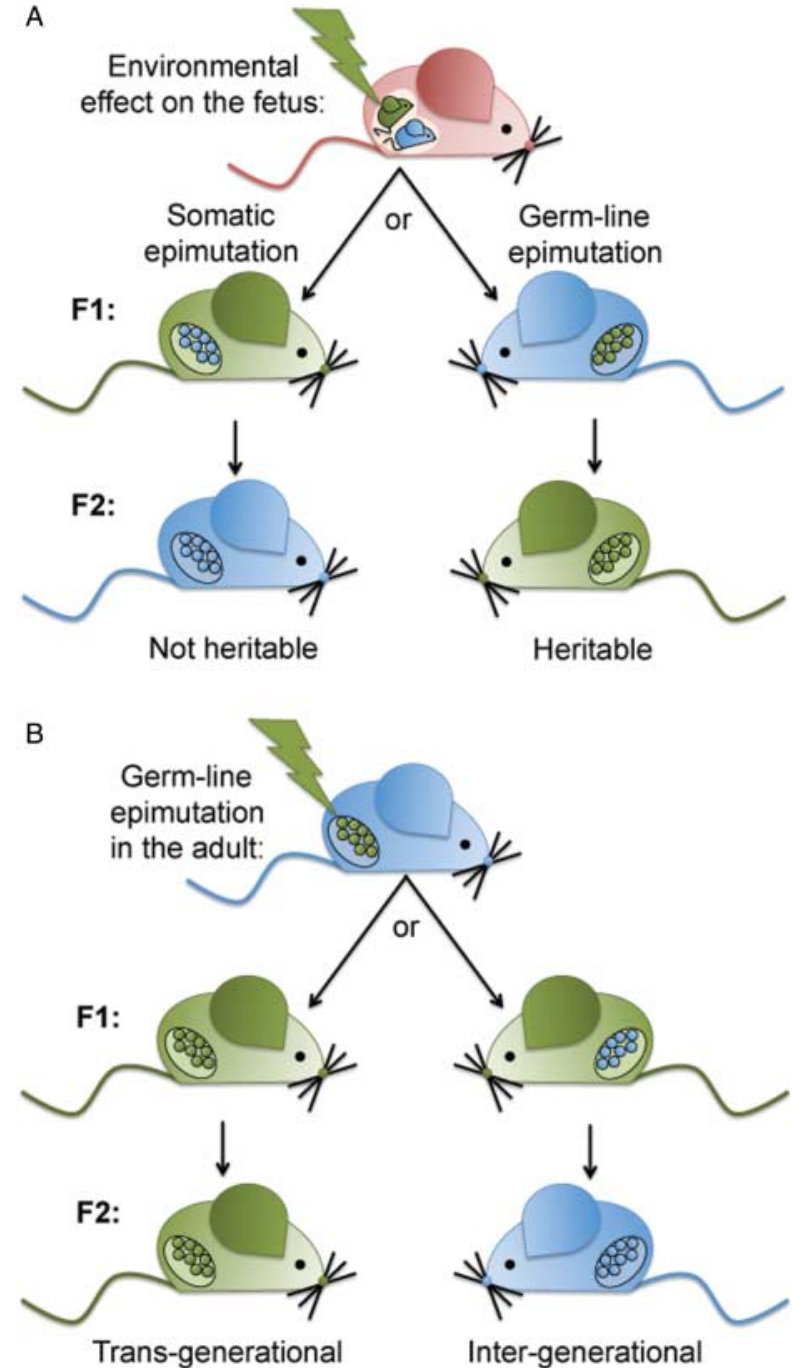

Figure 4 Models of epigenetic inheritance. (A) Chemicals or environmental agents could alter the epigenome of the fetus (F1), resulting in either somatic (blue germ cells, left) or germ-line epimutations (green germ cells, right). Somatic epimutations may affect the F1 fetus but are not heritable between generations (left). Germ-line epimutations will be inherited in the F2 animals and may affect development, assuming that the epimutation is not reprogrammed in the pre-implantation embryo. (B) If a germ-line epimutation is inherited and maintained over several generations, it may mediate transgenerational affects. However, if such an epimutation is reprogrammed in the germ-line of the F1 individual and is not inherited by the following generations, it may have only an inter-generational affect. Blue and pink mice are epigenetically normal male and female mice respectively. Green mice carry a somatic epimutation. Blue germ cells are epigenetically normal and green germ cells carry an epimutation.

and the third generation was obtained from insulinresistant F2 dams. Therefore, it remains possible that the second- and third-generation phenotypes may be the result of the maternal environment, which confounds identification of trans-generational effects in these studies. The confounding effects of maternal environment may be avoided if similar phenotypes could be 
demonstrated by transmission through the paternal germ-line. A similar study demonstrated that a maternal high-fat diet results in increased body length and insulin insensitivity in the mother's pups. While this phenotype was maternally and paternally transmitted over the first two generations, in the third generation, increased body length was only detected in the female offspring and was only paternally transmitted (Dunn \& Bale 2011). Although imprinted genes have been implicated, the molecular mechanisms underlying inheritance of these phenotypes remain unknown.

Other studies have more directly demonstrated that mutations in epigenetic modifiers can result in paternal inheritance of epigenetic effects (Chong et al. 2007). Haploinsufficiency of Dnmt1 and Smarca5 in male mice caused changes in expression of the maternally inherited $A^{v y}$ gene in genetically wild-type offspring (Chong et al. 2007). This demonstrates a trans-effect on maternal gene expression that is apparently mediated through a paternally inherited epigenetic mechanism. Although the identity and function of the pathways involved are yet to be understood, the authors speculated that noncoding RNAs might provide a molecular mechanism for inheritance of the epigenetic effects in these models. In support of this, studies on $C$. elegans demonstrate that molecular mechanisms underlying paternal epigenetic inheritance involve small non-coding RNAs, particularly piRNAs, and histone-modifying proteins (Ashe et al. 2012, Buckley et al. 2012, Gu et al. 2012). Indeed, recent studies have used RNA sequencing to identify sperm RNAs that could be passed to the next generation (Krawetz et al. 2011, Peng et al. 2012, Sendler et al. 2013), where they might contribute to patterning the epigenetic state.

Induction of epimutations in the germ-line could involve mutations in genes regulating epigenetic state (Chong et al. 2007) or be mediated through environmental influences, such as chemicals and toxins (Anway et al. 2005). Hence, even if the embryo is genetically normal, environmentally induced germ-line epimutations may be transmitted through the gametes and underlie phenotypic variation, including diseases and disorders in the parent's offspring (Fig. 4). As variation in epigenetic patterning is likely to affect many target genes, germ-line epimutations could underlie a range of developmental disorders in the next generation.

\section{Trans-generational vs inter-generational effects}

Trans-generational effects are considered to result from epimutations established in the germ-line that are stable through multiple generations (Fig. 4b). To be transmitted across multiple generations, epimutations must survive germ-line reprogramming. This could occur through two different mechanisms. First, an epimutation in the germline may be resistant to, or lack factors that mediate, epigenetic erasure during germ cell development.
Alternatively, there could be a persistent change in the memory mechanism governing where specific epigenetic modification(s) are re-established in the chromatin of developing germ cells (Fig. 3). Either way, transgenerational epimutations could contribute significantly to evolutionary mechanisms that respond to environmental change at a more rapid rate than selection for genetic mutations. However, if such mechanisms are to be responsive to environmental cues and avoid the relative persistence of a genetic mutation, germ-line epimutations underlying trans-generational changes should be reversible or changeable.

Epimutations induced in the F1 germ-line, either through impacts on the fetus during pregnancy or on the germ-line in post-natal life of individuals of the F1 generation, may also affect the F2 generation but not subsequent generations (Fig. 4). Such effects can be considered inter-generational, as the effect is not maintained past the F1 progeny. Although potentially less important in an evolutionary sense, relatively shortlived inter-generational epigenetic changes could have significant impacts on human health, especially if the germ-lines of consecutive or non-consecutive generations are exposed to the same or similar environmental influences such as chemicals, drugs or toxins. Therefore, it may be less important to understand whether an epimutation persists in a trans-generational or intergenerational sense and initially more important to understand how epigenetic information is transmitted through the germ-line.

\section{Early embryonic reprogramming}

To mediate the effects in the fetus or during post-natal life, epimutations must be sustained through preimplantation development. However, fertilisation induces genome-wide epigenetic reprogramming that is thought to allow reacquisition of totipotency in the zygote (Howlett \& Reik 1991, Santos et al. 2002, Borgel et al. 2010, Smallwood et al. 2011, Gillich et al. 2012, Smallwood \& Kelsey 2012, Smith et al. 2012). There have been several other studies that have reached somewhat varied conclusions regarding the extent of epigenetic reprogramming during pre-implantation development. Studies in a variety of mammalian models using immunofluorescence suggest that up to $90 \%$ of DNA methylation is removed after the first cell cycle (Mayer et al. 2000, Dean et al. 2001, Reik et al. 2001, Santos et al. 2002). Bisulphite analysis at specific loci also revealed DNA demethylation in the zygote, although to a lesser extent than that indicated by immunofluorescence (Oswald et al. 2000, Lane et al. 2003). Moreover, in a recent study using global DNA bisulphite sequencing, it was demonstrated that oocytes are initially hypomethylated compared with sperm (Smith et al. 2012). However, during pre-implantation reprogramming, the paternal genome is demethylated 
such that the DNA methylation levels in the zygote are similar to those in the oocyte (Smith et al. 2012). Extensive analysis of CGIs using reduced-representation bisulphite sequencing demonstrated that significant loss of $5 \mathrm{mC}$ occurred during pre-implantation development, although the levels of $5 \mathrm{mC}$ in the blastocyst were higher than those expected (Smallwood et al. 2011). This is consistent with the studies that have shown resistance of some non-imprinted genes to demethylation during preimplantation development (Borgel et al. 2010, Smith et al. 2012) and that the paternal pronucleus maintains a relatively high level of DNA methylation well into embryonic development ( $\mathrm{Li} \&$ O'Neill 2012). Data obtained from human zygotes are also inconsistent; in some cases, $\sim 30 \%$ of the DNA methylation is lost from the paternal pronucleus, while other studies show no loss of methylation (Fulka et al. 2004). Similarly, no loss of DNA methylation was observed in either pronucleus of bovine or rabbit zygotes sourced in vivo and only partial demethylation was observed in bovine zygotes (Beaujean et al. 2004). Therefore, while reprogramming appears to be widespread during preimplantation development, the data are variable and it appears likely that in addition to imprinted genes, DNA methylation and possibly other epigenetic information may be maintained at some non-imprinted genes.

The clearest examples of inherited epigenetic effects in offspring involve imprinted genes, for which some parent-specific epigenetic marks are maintained throughout life. How this epigenetic information is maintained through pre-implantation reprogramming is poorly understood. However, recent experiments have demonstrated that maternal loss of proteins encoded by Stella, Zfp57 and Trim28 is associated with loss of genomic imprinting in the zygote and have provided some insights into this process (Nakamura et al. 2007, Li et al. 2008, Messerschmidt et al. 2012, Szabo \& Pfeifer 2012). Although it is not yet clear how these proteins protect imprints, loss of these and other maternal proteins may also affect other epigenetic modifications that would normally be retained through pre-implantation embryonic development. Further insights into these, and other similar mechanisms, will be central to understanding how epigenetic information is processed in early development and how epigenetic information provided by the gametes is transmitted through this stage to affect later development.

\section{Conclusions}

Both female and male germ cells are derived from PGCs, which undergo genome-wide reprogramming during their migration to the developing gonads. Reprogramming in the germ-line is essential to reset parent-specific epigenetic information, such as genomic imprints, and is potentially required for establishment of sex-specific germ-line development and identity. It is clear that epigenetic information is established during germ-line development and is passed from parent to progeny through the gametes. Thus, epimutations acquired in the parental generation have the potential to be transmitted and affect the development in the next generation(s). This has significant implications for our understanding of inherited disorders and the long-term impact of chemicals and drugs in our environment. Moreover, trans-generational inheritance of environmentally induced epigenetic change may contribute to an organism's ability to adapt to environmental influences. Further studies examining the molecular mechanisms for inter-generational and trans-generational epigenetic effects are essential for understanding the potential for the environment to directly affect a parent's offspring and induce multi-generationally inherited traits and diseases.

\section{Declaration of interest}

The authors declare that there is no conflict of interest that could be perceived as prejudicing the impartiality of the research reported.

\section{Funding}

This work was supported by funding from the Monash University Faculty of Medicine, Nursing and Health Sciences funding granted to P W and the Victorian Government's Operational Infrastructure Support Program. JS, SB and PW are supported by National Health and Medical Research Grants 1043939 and 1051223 awarded to PW.

\section{References}

Abramowitz LK \& Bartolomei MS 2012 Genomic imprinting: recognition and marking of imprinted loci. Current Opinion in Genetics \& Development 22 72-78. (doi:10.1016/j.gde.2011.12.001)

Ancelin K, Lange UC, Hajkova P, Schneider R, Bannister AJ, Kouzarides T \& Surani MA 2006 Blimp1 associates with Prmt5 and directs histone arginine methylation in mouse germ cells. Nature Cell Biology 8 623-630. (doi:10.1038/ncb1413)

Anway MD, Cupp AS, Uzumcu M \& Skinner MK 2005 Epigenetic transgenerational actions of endocrine disruptors and male fertility. Science 308 1466-1469. (doi:10.1126/science.1108190)

Aravin AA \& Bourc'his D 2008 Small RNA guides for de novo DNA methylation in mammalian germ cells. Genes and Development 22 970-975. (doi:10.1101/gad.1669408)

Aravin AA, Sachidanandam R, Bourc'his D, Schaefer C, Pezic D, Toth KF, Bestor T \& Hannon GJ 2008 A piRNA pathway primed by individual transposons is linked to de novo DNA methylation in mice. Molecular Cell 31 785-799. (doi:10.1016/j.molcel.2008.09.003)

Arnaud P 2010 Genomic imprinting in germ cells: imprints are under control. Reproduction 140 411-423. (doi:10.1530/REP-10-0173)

Ashe A, Sapetschnig A, Weick EM, Mitchell J, Bagijn MP, Cording AC, Doebley AL, Goldstein LD, Lehrbach NJ, Le Pen J et al. 2012 piRNAs can trigger a multigenerational epigenetic memory in the germline of $C$. elegans. Cell 150 88-99. (doi:10.1016/j.cell.2012.06.018)

Balhorn R, Gledhill BL \& Wyrobek AJ 1977 Mouse sperm chromatin proteins: quantitative isolation and partial characterization. Biochemistry 16 4074-4080. (doi:10.1021/bi00637a021) 
Baltus AE, Menke DB, Hu YC, Goodheart ML, Carpenter AE, de Rooij DG \& Page DC 2006 In germ cells of mouse embryonic ovaries, the decision to enter meiosis precedes premeiotic DNA replication. [see comment]. Nature Genetics 38 1430-1434. (doi:10.1038/ng1919)

Bamezai S, Rawat VP \& Buske C 2012 Concise review: the Piwi-piRNA axis: pivotal beyond transposon silencing. Stem Cells 30 2603-2611. (doi:10.1002/stem.1237)

Bartolomei MS \& Ferguson-Smith AC 2011 Mammalian genomic imprinting. Cold Spring Harbor Perspectives in Biology 3 a002592. (doi:10.1101/cshperspect.a002592)

Barton SC, Surani MA \& Norris ML 1984 Role of paternal and maternal genomes in mouse development. Nature 311 374-376. (doi:10.1038/ 311374a0)

Beaujean N, Hartshorne G, Cavilla J, Taylor J, Gardner J, Wilmut I, Meehan R \& Young L 2004 Non-conservation of mammalian preimplantation methylation dynamics. Current Biology 14 R266-R267. (doi:10.1016/j.cub.2004.03.019)

Benyshek DC, Johnston CS \& Martin JF 2004 Post-natal diet determines insulin resistance in fetally malnourished, low birthweight rats (F1) but diet does not modify the insulin resistance of their offspring (F2). Life Sciences 74 3033-3041. (doi:10.1016/j.Ifs.2003.11.008)

Benyshek D, Johnston C \& Martin J 2006 Glucose metabolism is altered in the adequately-nourished grand-offspring (F3 generation) of rats malnourished during gestation and perinatal life. Diabetologia 49 1117-1119. (doi:10.1007/s00125-006-0196-5)

Bhutani N, Brady JJ, Damian M, Sacco A, Corbel SY \& Blau HM 2010 Reprogramming towards pluripotency requires AID-dependent DNA demethylation. Nature 463 1042-1047. (doi:10.1038/nature08752)

Borgel J, Guibert S, Li Y, Chiba H, Schubeler D, Sasaki H, Forne T \& Weber M 2010 Targets and dynamics of promoter DNA methylation during early mouse development. Nature Genetics 42 1093-1100. (doi:10.1038/ng.708)

Bourc'his D \& Bestor TH 2004 Meiotic catastrophe and retrotransposon reactivation in male germ cells lacking Dnmt3L. Nature 431 96-99. (doi:10.1038/nature02886)

Bourc'his D, Xu GL, Lin CS, Bollman B \& Bestor TH 2001 Dnmt3L and the establishment of maternal genomic imprints. Science 294 2536-2539. (doi:10.1126/science.1065848)

Bowles J, Feng CW, Spiller C, Davidson TL, Jackson A \& Koopman P 2010 FGF9 suppresses meiosis and promotes male germ cell fate in mice. Developmental Cell 19 440-449. (doi:10.1016/j.devcel.2010.08.010)

Brykczynska U, Hisano M, Erkek S, Ramos L, Oakeley EJ, Roloff TC, Beisel C, Schubeler D, Stadler MB \& Peters AH 2010 Repressive and active histone methylation mark distinct promoters in human and mouse spermatozoa. Nature Structural \& Molecular Biology 17 679-687. (doi:10.1038/nsmb.1821)

Buckley BA, Burkhart KB, Gu SG, Spracklin G, Kershner A, Fritz H, Kimble J, Fire A \& Kennedy S 2012 A nuclear argonaute promotes multigenerational epigenetic inheritance and germline immortality. Nature 489 447-451. (doi:10.1038/nature11352)

Chedin F, Lieber MR \& Hsieh CL 2002 The DNA methyltransferase-like protein DNMT3L stimulates de novo methylation by Dnmt3a. PNAS 99 16916-16921. (doi:10.1073/pnas.262443999)

Chong S, Vickaryous N, Ashe A, Zamudio N, Youngson N, Hemley S, Stopka T, Skoultchi A, Matthews J, Scott HS et al. 2007 Modifiers of epigenetic reprogramming show paternal effects in the mouse. Nature Genetics 39 614-622. (doi:10.1038/ng2031)

Cirio MC, Ratnam S, Ding F, Reinhart B, Navara C \& Chaillet JR 2008 Preimplantation expression of the somatic form of Dnmt1 suggests a role in the inheritance of genomic imprints. BMC Developmental Biology 89. (doi:10.1186/1471-213X-8-9)

Constancia M, Pickard B, Kelsey G \& Reik W 1998 Imprinting mechanisms. Genome Research 8 881-900. (doi:10.1101/gr.8.9.881)

Dahri S, Snoeck A, Reusens-Billen B, Remacle C \& Hoet JJ 1991 Islet function in offspring of mothers on low-protein diet during gestation. Diabetes 40 (Suppl 2) 115-120.

Davis TL, Trasler JM, Moss SB, Yang GJ \& Bartolomei MS 1999 Acquisition of the $\mathrm{H} 19$ methylation imprint occurs differentially on the parental alleles during spermatogenesis. Genomics 58 18-28. (doi:10.1006/geno. 1999.5813)
Davis TL, Yang GJ, McCarrey JR \& Bartolomei MS 2000 The H19 methylation imprint is erased and re-established differentially on the parental alleles during male germ cell development. Human Molecular Genetics 9 2885-2894. (doi:10.1093/hmg/9.19.2885)

Dean W, Santos F, Stojkovic M, Zakhartchenko V, Walter J, Wolf E \& Reik W 2001 Conservation of methylation reprogramming in mammalian development: aberrant reprogramming in cloned embryos. PNAS 98 13734-13738. (doi:10.1073/pnas.241522698)

DeFalco T \& Capel B 2009 Gonad morphogenesis in vertebrates: divergent means to a convergent end. Annual Review of Cell and Developmental Biology 25 457-482. (doi:10.1146/annurev.cellbio.042308.13350)

Delaval K, Govin J, Cerqueira F, Rousseaux S, Khochbin S \& Feil R 2007 Differential histone modifications mark mouse imprinting control regions during spermatogenesis. EMBO Journal 26 720-729. (doi:10.1038/ sj.emboj.7601513)

Dong KB, Maksakova IA, Mohn F, Leung D, Appanah R, Lee S, Yang HW, Lam LL, Mager DL, Schubeler D et al. 2008 DNA methylation in ES cells requires the lysine methyltransferase G9a but not its catalytic activity. EMBO Journal 27 2691-2701. (doi:10.1038/emboj.2008.193)

Dunn GA \& Bale TL 2011 Maternal high-fat diet effects on third-generation female body size via the paternal lineage. Endocrinology 152 2228-2236. (doi:10.1210/en.2010-1461)

Edwards CA \& Ferguson-Smith AC 2007 Mechanisms regulating imprinted genes in clusters. Current Opinion in Cell Biology 19 281-289. (doi:10.1016/j.ceb.2007.04.013)

Fulka H, Mrazek M, Tepla O \& Fulka J Jr 2004 DNA methylation pattern in human zygotes and developing embryos. Reproduction 128 703-708. (doi:10.1530/rep.1.00217)

Gatewood JM, Cook GR, Balhorn R, Bradbury EM \& Schmid CW 1987 Sequence-specific packaging of DNA in human sperm chromatin. Science 236 962-964. (doi:10.1126/science.3576213)

Gillich A, Bao S, Grabole N, Hayashi K, Trotter MW, Pasque V, Magnusdottir E \& Surani MA 2012 Epiblast stem cell-based system reveals reprogramming synergy of germline factors. Cell Stem Cell $\mathbf{1 0}$ 425-439. (doi:10.1016/j.stem.2012.01.020)

Gkountela S, Li Z, Vincent JJ, Zhang KX, Chen A, Pellegrini M \& Clark AT 2013 The ontogeny of cKIT + human primordial germ cells proves to be a resource for human germ line reprogramming, imprint erasure and in vitro differentiation. Nature Cell Biology 15 113-122. (doi:10.1038/ ncb2638)

Gu SG, Pak J, Guang S, Maniar JM, Kennedy S \& Fire A 2012 Amplification of siRNA in Caenorhabditis elegans generates a transgenerational sequence-targeted histone $\mathrm{H} 3$ lysine 9 methylation footprint. Nature Genetics 44 157-164. (doi:10.1038/ng.1039)

Guibert S, Forne T \& Weber M 2012 Global profiling of DNA methylation erasure in mouse primordial germ cells. Genome Research 22 633-641. (doi:10.1101/gr.130997.111)

Hackett JA, Reddington JP, Nestor CE, Dunican DS, Branco MR, Reichmann J, Reik W, Surani MA, Adams IR \& Meehan RR 2012 Promoter DNA methylation couples genome-defence mechanisms to epigenetic reprogramming in the mouse germline. Development 139 3623-3632. (doi:10.1242/dev.081661)

Hackett JA, Sengupta R, Zylicz JJ, Murakami K, Lee C, Down TA \& Surani MA 2013 Germline DNA demethylation dynamics and imprint erasure through 5-hydroxymethylcytosine. Science 339 448-452. (doi:10.1126/science.1229277)

Hajkova P, Erhardt S, Lane N, Haaf T, El-Maarri O, Reik W, Walter J \& Surani MA 2002 Epigenetic reprogramming in mouse primordial germ cells. Mechanisms of Development 117 15-23. (doi:10.1016/S09254773(02)00181-8)

Hajkova P, Ancelin K, Waldmann T, Lacoste N, Lange UC, Cesari F, Lee C, Almouzni G, Schneider R \& Surani MA 2008 Chromatin dynamics during epigenetic reprogramming in the mouse germ line. Nature $\mathbf{4 5 2}$ 877-881. (doi:10.1038/nature06714)

Hajkova P, Jeffries SJ, Lee C, Miller N, Jackson SP \& Surani MA 2010 Genome-wide reprogramming in the mouse germ line entails the base excision repair pathway. Science 329 78-82. (doi:10.1126/science. 1187945)

Hammoud SS, Nix DA, Zhang H, Purwar J, Carrell DT \& Cairns BR 2009 Distinctive chromatin in human sperm packages genes for embryo development. Nature 460 473-478. (doi:10.1038/nature08162) 
Hata K, Okano M, Lei H \& Li E 2002 Dnmt3L cooperates with the Dnmt3 family of de novo DNA methyltransferases to establish maternal imprints in mice. Development 129 1983-1993.

Heijmans BT, Tobi EW, Stein AD, Putter H, Blauw GJ, Susser ES, Slagboom PE \& Lumey LH 2008 Persistent epigenetic differences associated with prenatal exposure to famine in humans. PNAS 105 17046-17049. (doi:10.1073/pnas.0806560105)

Henckel A, Nakabayashi K, Sanz LA, Feil R, Hata K \& Arnaud P 2009 Histone methylation is mechanistically linked to DNA methylation at imprinting control regions in mammals. Human Molecular Genetics 18 3375-3383. (doi:10.1093/hmg/ddp277)

Howlett SK \& Reik W 1991 Methylation levels of maternal and paternal genomes during preimplantation development. Development 113 119-127.

Ideraabdullah FY, Vigneau S \& Bartolomei MS 2008 Genomic imprinting mechanisms in mammals. Mutation Research/Fundamental and Molecular Mechanisms of Mutagenesis 647 77-85. (doi:10.1016/j.mrfmmm. 2008.08.008)

Ikegami D, Iwai T, Ryo S, Gu N, Sugiyama T, Oh I, Yoshikawa H \& Tsumaki N 2011 Identification of small molecular compounds and fabrication of its aqueous solution by laser-ablation, expanding primordial cartilage. Osteoarthritis and Cartilage 19 233-241. (doi:10.1016/ j.joca.2010.11.007)

Ito S, D'Alessio AC, Taranova OV, Hong K, Sowers LC \& Zhang Y 2010 Role of Tet proteins in $5 \mathrm{mC}$ to $5 \mathrm{hmC}$ conversion, ES-cell self-renewal and inner cell mass specification. Nature 466 1129-1133. (doi:10.1038/ nature09303)

Kagiwada S, Kurimoto K, Hirota T, Yamaji M \& Saitou M 2013 Replicationcoupled passive DNA demethylation for the erasure of genome imprints in mice. EMBO Journal 32 340-353. (doi:10.1038/emboj.2012.331)

Kaneda M, Okano M, Hata K, Sado T, Tsujimoto N, Li E \& Sasaki H 2004 Essential role for de novo DNA methyltransferase Dnmt3a in paternal and maternal imprinting. Nature 429 900-903. (doi:10.1038/ nature02633)

Kato Y, Kaneda M, Hata K, Kumaki K, Hisano M, Kohara Y, Okano M, Li E, Nozaki M \& Sasaki H 2007 Role of the Dnmt3 family in de novo methylation of imprinted and repetitive sequences during male germ cell development in the mouse. Human Molecular Genetics 16 2272-2280. (doi:10.1093/hmg/ddm179)

Kim J, Samaranayake M \& Pradhan S 2009 Epigenetic mechanisms in mammals. Cellular and Molecular Life Sciences 66 596-612. (doi:10.1007/s00018-008-8432-4)

Koubova J, Menke DB, Zhou Q, Capel B, Griswold MD \& Page DC 2006 Retinoic acid regulates sex-specific timing of meiotic initiation in mice PNAS 103 2474-2479. (doi:10.1073/pnas.0510813103)

Krawetz SA, Kruger A, Lalancette C, Tagett R, Anton E, Draghici S \& Diamond MP 2011 A survey of small RNAs in human sperm. Human Reproduction 26 3401-3412. (doi:10.1093/humrep/der329)

Kuramochi-Miyagawa S, Watanabe T, Gotoh K, Totoki Y, Toyoda A, Ikawa M, Asada N, Kojima K, Yamaguchi Y, ljiri TW et al. 2008 DNA methylation of retrotransposon genes is regulated by Piwi family members MILI and MIWI2 in murine fetal testes. Genes and Development 22 908-917. (doi:10.1101/gad.1640708)

Kurimoto K, Yabuta Y, Ohinata Y, Shigeta M, Yamanaka K \& Saitou M 2008a Complex genome-wide transcription dynamics orchestrated by Blimp1 for the specification of the germ cell lineage in mice. Genes and Development 22 1617-1635. (doi:10.1101/gad.1649908)

Kurimoto K, Yamaji M, Seki Y \& Saitou M 2008b Specification of the germ cell lineage in mice: a process orchestrated by the PR-domain proteins, Blimp1 and Prdm14. Cell Cycle 7 3514-3518. (doi:10.4161/cc.7.22. 6979)

Lane N, Dean W, Erhardt S, Hajkova P, Surani A, Walter J \& Reik W 2003 Resistance of IAPS to methylation reprogramming may provide a mechanism for epigenetic inheritance in the mouse. Genesis 35 88-93. (doi:10.1002/gene.10168)

Lees-Murdock DJ, De Felici M \& Walsh CP 2003 Methylation dynamics of repetitive DNA elements in the mouse germ cell lineage. Genomics $\mathbf{8 2}$ 230-237. (doi:10.1016/S0888-7543(03)00105-8)

Leung DC, Dong KB, Maksakova IA, Goyal P, Appanah R, Lee S, Tachibana M, Shinkai Y, Lehnertz B, Mager DL et al. 2011 Lysine methyltransferase G9a is required for de novo DNA methylation and the establishment, but not the maintenance, of proviral silencing. PNAS $\mathbf{1 0 8}$ 5718-5723. (doi:10.1073/pnas.1014660108)

Li Y \& O'Neill C 2012 Persistence of cytosine methylation of DNA following fertilisation in the mouse. PLOS ONE 7 e30687. (doi:10.1371/journal. pone.0030687)

Li JY, Lees-Murdock DJ, Xu GL \& Walsh CP 2004 Timing of establishment of paternal methylation imprints in the mouse. Genomics 84 952-960. (doi:10.1016/j.ygeno.2004.08.012)

Li X, Ito M, Zhou F, Youngson N, Zuo X, Leder P \& Ferguson-Smith AC 2008 A maternal-zygotic effect gene, Zfp57, maintains both maternal and paternal imprints. Developmental Cell 15 547-557. (doi:10.1016/j. devcel.2008.08.014)

Lucifero D, Mann MR, Bartolomei MS \& Trasler JM 2004 Gene-specific timing and epigenetic memory in oocyte imprinting. Human Molecular Genetics 13 839-849. (doi:10.1093/hmg/ddh104)

Lucifero D, La Salle S, Bourc'his D, Martel J, Bestor TH \& Trasler JM 2007 Coordinate regulation of DNA methyltransferase expression during oogenesis. BMC Developmental Biology 7 36. (doi:10.1186/1471213X-7-36)

Magnusdottir E, Gillich A, Grabole N \& Surani MA 2012 Combinatorial control of cell fate and reprogramming in the mammalian germline. Current Opinion in Genetics \& Development 22 466-474. (doi:10.1016/ j.gde.2012.06.002)

Mansour AA, Gafni O, Weinberger L, Zviran A, Ayyash M, Rais Y, Krupalnik V, Zerbib M, Amann-Zalcenstein D, Maza I et al. 2012 The H3K27 demethylase Utx regulates somatic and germ cell epigenetic reprogramming. Nature $\mathbf{4 8 8}$ 409-413. (doi:10.1038/nature11272)

Martin JF, Johnston CS, Han CT \& Benyshek DC 2000 Nutritional origins of insulin resistance: a rat model for diabetes-prone human populations. Journal of Nutrition 130 741-744.

Mayer W, Niveleau A, Walter J, Fundele R \& Haaf T 2000 Demethylation of the zygotic paternal genome. Nature 403 501-502. (doi:10.1038/ 35000656)

McGrath J \& Solter D 1984 Completion of mouse embryogenesis requires both the maternal and paternal genomes. Cell 37 179-183. (doi:10.1016/0092-8674(84)90313-1)

Messerschmidt DM, de Vries W, Ito M, Solter D, Ferguson-Smith A \& Knowles BB 2012 Trim28 is required for epigenetic stability during mouse oocyte to embryo transition. Science 335 1499-1502. (doi:10.1126/science.1216154)

Miles DC \& Western PS 2012 Germ cell sex and cell cycle. Histology and Histopathology 27 445-457.

Miles DC, Wakeling SI, Stringer JM, van den Bergen JA, Wilhelm D, Sinclair AH \& Western PS 2013 Signaling through the TGF $\beta$ activin receptors ALK4/5/7 regulates testis formation and male germ cell development. PLOS ONE 8 e54606. (doi:10.1371/journal.pone. 0054606)

Nakamura T, Arai Y, Umehara H, Masuhara M, Kimura T, Taniguchi $\mathbf{H}$, Sekimoto T, Ikawa M, Yoneda Y, Okabe M et al. 2007 PGC7/Stella protects against DNA demethylation in early embryogenesis. Nature Cell Biology 9 64-71. (doi:10.1038/ncb1519)

Ohinata Y, Payer B, O'Carroll D, Ancelin K, Ono Y, Sano M, Barton SC, Obukhanych T, Nussenzweig M, Tarakhovsky A et al. 2005 Blimp1 is a critical determinant of the germ cell lineage in mice. Nature 436 207-213. (doi:10.1038/nature03813)

Oswald J, Engemann S, Lane N, Mayer W, Olek A, Fundele R, Dean W, Reik W \& Walter J 2000 Active demethylation of the paternal genome in the mouse zygote. Current Biology 10 475-478. (doi:10.1016/S09609822(00)00448-6)

Peng H, Shi J, Zhang Y, Zhang H, Liao S, Li W, Lei L, Han C, Ning L, Cao Y et al. 2012 A novel class of tRNA-derived small RNAs extremely enriched in mature mouse sperm. Cell Research 22 1609-1612. (doi:10.1038/cr.2012.141)

Popp C, Dean W, Feng S, Cokus SJ, Andrews S, Pellegrini M, Jacobsen SE \& Reik W 2010 Genome-wide erasure of DNA methylation in mouse primordial germ cells is affected by AID deficiency. Nature 463 1101-1105. (doi:10.1038/nature08829)

Ravelli G-P, Stein ZA \& Susser MW 1976 Obesity in young men after famine exposure in utero and early infancy. New England Journal of Medicine 295 349-353. (doi:10.1056/NEJM197608122950701) 
Reik W \& Walter J 1998 Imprinting mechanisms in mammals. Current Opinion in Genetics \& Development 8 154-164. (doi:10.1016/S0959437X(98)80136-6)

Reik W \& Walter J 2001 Genomic imprinting: parental influence on the genome. Nature Reviews. Genetics 2 21-32. (doi:10.1038/35047554)

Reik W, Dean W \& Walter J 2001 Epigenetic reprogramming in mammalian development. Science 293 1089-1093. (doi:10.1126/science.1063443)

Saitou M \& Yamaji M 2010 Germ cell specification in mice: signaling, transcription regulation, and epigenetic consequences. Reproduction 139 931-942. (doi:10.1530/REP-10-0043)

Sakai Y, Suetake I, Shinozaki F, Yamashina S \& Tajima S 2004 Co-expression of de novo DNA methyltransferases Dnmt3a2 and Dnmt3L in gonocytes of mouse embryos. Gene Expression Patterns 5 231-237. (doi:10.1016/j. modgep.2004.07.011)

Santos F, Hendrich B, Reik W \& Dean W 2002 Dynamic reprogramming of DNA methylation in the early mouse embryo. Developmental Biology 241 172-182. (doi:10.1006/dbio.2001.0501)

Seisenberger S, Andrews S, Krueger F, Arand J, Walter J, Santos F, Popp C, Thienpont B, Dean W \& Reik W 2012 The dynamics of genome-wide DNA methylation reprogramming in mouse primordial germ cells. Molecular Cell 48 849-862. (doi:10.1016/j.molcel.2012.11.001)

Seki Y, Hayashi K, Itoh K, Mizugaki M, Saitou M \& Matsui Y 2005 Extensive and orderly reprogramming of genome-wide chromatin modifications associated with specification and early development of germ cells in mice. Developmental Biology 278 440-458. (doi:10.1016/j.ydbio.2004. 11.025)

Seki Y, Yamaji M, Yabuta Y, Sano M, Shigeta M, Matsui Y, Saga Y, Tachibana M, Shinkai Y \& Saitou M 2007 Cellular dynamics associated with the genome-wide epigenetic reprogramming in migrating primordial germ cells in mice. Development 134 2627-2638. (doi:10.1242/ dev.005611)

Sendler E, Johnson GD, Mao S, Goodrich RJ, Diamond MP, Hauser R \& Krawetz SA 2013 Stability, delivery and functions of human sperm RNAs at fertilization. Nucleic Acids Research 41 4104-4117. (doi:10.1093/ nar/gkt132)

Sha K 2008 A mechanistic view of genomic imprinting. Annual Review of Genomics and Human Genetics 9 197-216. (doi:10.1146/annurev. genom.122007.110031)

Sharif J, Muto M, Takebayashi S, Suetake I, Iwamatsu A, Endo TA, Shinga J, Mizutani-Koseki Y, Toyoda T, Okamura K et al. 2007 The SRA protein Np95 mediates epigenetic inheritance by recruiting Dnmt1 to methylated DNA. Nature 450 908-912. (doi:10.1038/nature06397)

Shovlin TC, Bourc'his D, La Salle S, O'Doherty A, Trasler JM, Bestor TH \& Walsh CP 2007 Sex-specific promoters regulate Dnmt3L expression in mouse germ cells. Human Reproduction 22 457-467. (doi:10.1093/ humrep/del379)

Siomi MC, Sato K, Pezic D \& Aravin AA 2011 PIWI-interacting small RNAs: the vanguard of genome defence. Nature Reviews. Molecular Cell Biology 12 246-258. (doi:10.1038/nrm3089)

Skinner MK 2010 Metabolic disorders: fathers' nutritional legacy. Nature 467 922-923. (doi:10.1038/467922a)

Skinner MK \& Guerrero-Bosagna C 2009 Environmental signals and transgenerational epigenetics. Epigenomics 1 111-117. (doi:10.2217/ epi.09.11)

Smallwood SA \& Kelsey G 2012 De novo DNA methylation: a germ cell perspective. Trends in Genetics 28 33-42. (doi:10.1016/j.tig.2011. 09.004)

Smallwood SA, Tomizawa S, Krueger F, Ruf N, Carli N, Segonds-Pichon A, Sato S, Hata K, Andrews SR \& Kelsey G 2011 Dynamic CpG island methylation landscape in oocytes and preimplantation embryos. Nature Genetics 43 811-814. (doi:10.1038/ng.864)

Smith ZD, Chan MM, Mikkelsen TS, Gu H, Gnirke A, Regev A \& Meissner A 2012 A unique regulatory phase of DNA methylation in the early mammalian embryo. Nature 484 339-344. (doi:10.1038/nature10960)

Souquet B, Tourpin S, Messiaen S, Moison D, Habert R \& Livera G 2012 Nodal signaling regulates the entry into meiosis in fetal germ cells. Endocrinology 153 2466-2473. (doi:10.1210/en.2011-2056)
Spiller CM, Feng CW, Jackson A, Gillis AJ, Rolland AD, Looijenga LH, Koopman P \& Bowles J 2012 Endogenous nodal signaling regulates germ cell potency during mammalian testis development. Development 139 4123-4132. (doi:10.1242/dev.083006)

Strome S \& Lehmann R 2007 Germ versus soma decisions: lessons from flies and worms. Science 316 392-393. (doi:10.1126/science.1140846)

Surani MA 1991 Influence of genome imprinting on gene expression, phenotypic variations and development. Human Reproduction 6 45-51.

Surani MA 1994 Genomic imprinting: control of gene expression by epigenetic inheritance. Current Opinion in Cell Biology 6 390-395. (doi:10.1016/0955-0674(94)90031-0)

Surani MA 2001 Reprogramming of genome function through epigenetic inheritance. Nature 414 122-128. (doi:10.1038/35102186)

Surani MA 2007 Germ cells: the eternal link between generations. Comptes Rendus Biologies 330 474-478. (doi:10.1016/j.crvi.2007.03.009)

Surani MA, Barton SC \& Norris ML 1984 Development of reconstituted mouse eggs suggests imprinting of the genome during gametogenesis. Nature 308 548-550. (doi:10.1038/308548a0)

Surani MA, Hayashi K \& Hajkova P 2007 Genetic and epigenetic regulators of pluripotency. Cell 128 747-762. (doi:10.1016/j.cell.2007.02.010)

Szabo PE \& Pfeifer GP 2012 H3K9me2 attracts PGC7 in the zygote to prevent Tet3-mediated oxidation of 5-methylcytosine. Journal of Molecular Cell Biology 4 427-429. (doi:10.1093/jmcb/mjs038)

Tachibana M, Ueda J, Fukuda M, Takeda N, Ohta T, Iwanari H, Sakihama T, Kodama T, Hamakubo T \& Shinkai Y 2005 Histone methyltransferases G9a and GLP form heteromeric complexes and are both crucial for methylation of euchromatin at H3-K9. Genes and Development 19 815-826. (doi:10.1101/gad.1284005)

Tachibana M, Matsumura Y, Fukuda M, Kimura H \& Shinkai Y 2008 G9a/GLP complexes independently mediate H3K9 and DNA methylation to silence transcription. EMBO Journal 27 2681-2690. (doi:10.1038/ emboj.2008.192)

Tanphaichitr N, Sobhon P, Taluppeth N \& Chalermisarachai P 1978 Basic nuclear proteins in testicular cells and ejaculated spermatozoa in man. Experimental Cell Research 117 347-356. (doi:10.1016/00144827(78)90148-9)

Weaver JR, Susiarjo M \& Bartolomei MS 2009 Imprinting and epigenetic changes in the early embryo. Mammalian Genome 20 532-543. (doi:10.1007/s00335-009-9225-2)

Webster KE, O'Bryan MK, Fletcher S, Crewther PE, Aapola U, Craig J, Harrison DK, Aung H, Phutikanit N, Lyle R et al. 2005 Meiotic and epigenetic defects in Dnmt3L-knockout mouse spermatogenesis. PNAS 102 4068-4073. (doi:10.1073/pnas.0500702102)

Western P 2009 Foetal germ cells: striking the balance between pluripotency and differentiation. International Journal of Developmental Biology 53 393-409. (doi:10.1387/ijdb.082671pw)

Yabuta Y, Kurimoto K, Ohinata Y, Seki Y \& Saitou M 2006 Gene expression dynamics during germline specification in mice identified by quantitative single-cell gene expression profiling. Biology of Reproduction $\mathbf{7 5}$ 705-716. (doi:10.1095/biolreprod.106.053686)

Yamaguchi S, Hong K, Liu R, Shen L, Inoue A, Diep D, Zhang K \& Zhang Y 2012 Tet1 controls meiosis by regulating meiotic gene expression. Nature 492 443-447. (doi:10.1038/nature11709)

Yamaji M, Seki Y, Kurimoto K, Yabuta Y, Yuasa M, Shigeta M, Yamanaka K, Ohinata Y \& Saitou M 2008 Critical function of Prdm14 for the establishment of the germ cell lineage in mice. Nature Genetics 40 1016-1022. (doi:10.1038/ng.186)

Received 25 December 2012

First decision 29 January 2013

Revised manuscript received 22 April 2013

Accepted 30 April 2013 